\title{
Current Insights into the Effectiveness of Riparian Management, Attainment of Multiple Benefits, and Potential Technical Enhancements
}

\author{
Marc Stutter,* Brian Kronvang, Daire Ó hUallacháin, and Joachim Rozemeijer
}

\begin{abstract}
Buffer strips between land and waters are widely applied measures in diffuse pollution management, with desired outcomes across other factors. There remains a need for evidence of pollution mitigation and wider habitat and societal benefits across scales. This paper synthesizes a collection of 16 new primary studies and review papers to provide the latest insights into riparian management. We focus on the following areas: (i) diffuse pollution removal efficiency of conventional and saturated buffer strips, (ii) enhancing biodiversity of buffers, (iii) edge-of-field technologies for improving nutrient retention, and (iv) potential reuse of nutrients and biomass from buffers. Although some topics represent emerging areas, for other well-studied topics (e.g., diffuse pollution), it remains that effectiveness of conventional vegetated buffer strips for water quality improvement varies. The collective findings highlight the merits of targeted, designed buffers that support multiple benefits, more efficiently interrupting surface and subsurface contaminant flows while enhancing diversity in surface topography, soil moisture and $C$, vegetation, and habitat. This synthesis also highlights that despite the significant number of studies on the functioning of riparian buffers, research gaps remain, particularly in relation to (i) the capture and retention of soluble $\mathrm{P}$ and $\mathrm{N}$ in subsurface flows through buffers, (ii) the utilization of captured nutrients, (iii) the impact of buffer design and management on terrestrial and aquatic habitats and species, and (iv) the effect of buffers (saturated) on greenhouse gas emissions and the potential for pollution swapping.
\end{abstract}

\section{Core Ideas}

- We present an updated synthesis on riparian management incorporating insights from 16 new papers.

- Topics cover diffuse pollution, biodiversity, new technologies, and biomass reuse.

- The synthesis shows a move toward designed elements to improve riparian functions.

Copyright $\odot$ American Society of Agronomy, Crop Science Society of America, and Soil Science Society of America. 5585 Guilford Rd., Madison, WI 53711 USA.

All rights reserved.

J. Environ. Qual. 48:236-247 (2019)

doi:10.2134/jeq2019.01.0020

This is an open access article distributed under the terms of the CC BY-NC-ND

license (http://creativecommons.org/licenses/by-nc-nd/4.0/)

Received 23 Jan. 2019.

Accepted 11 Feb. 2019

*Corresponding author (marc.stutter@hutton.ac.uk).
$\mathrm{R}$ IPARIAN BUFFERS have been one of the most widely used management options worldwide when dealing with protection of surface waters from agricultural diffuse pollution. Appropriately managed riparian areas offer multiple functions related to improving water quality, biodiversity, and climate adaptation. First, riparian areas offer possibilities for protecting watercourses and lakes from inputs of sediments, nutrients, pesticides, and other contaminants by intercepting surface runoff, tile drainage, and groundwater from adjoining agricultural fields. Second, riparian areas also offer unique biodiversity (in turn affecting in-field and in-stream biodiversity) including structurally complex layers of vegetation, making them attractive to many wildlife species (Naiman et al., 1993). The vegetation and habitat may be managed for many aspects including wildlife corridors, stream shading, introducing pollinators, biomass, and agroforestry. Lastly, riparian areas with diverse, often wet, moisture conditions and high plant biomass create soils of high organic $\mathrm{C}$ contents. These soils are therefore of importance for $\mathrm{C}$ sequestration and should be protected from draining. Overall, the importance of the semi-wet riparian ecotones between the aquatic environment and higherlying drier soils cannot be overestimated.

Depending on desired outcomes, a range of practices can be applied to riparian areas, including exclusion of agricultural cultivation and grazing, vegetation management, provision of floodwater storage, bank stabilization, and soil management to promote or limit certain pollution processes. The designs and areas given to them are hugely diverse, ranging from smaller-scale riparian buffer strips (widths $=1-5 \mathrm{~m}$, Fig. 1a and 1b; Stutter et al., 2012; Haddaway et al., 2018), to rewetted riparian buffers including constructed wetlands ( $<1$ ha; Land et al., 2016) and larger recreated wetlands (10 to $>100$ ha, Fig. 1c; Kristensen et al., 2014; Land et al., 2016; Windolf et al., 2016), to engineered designs in restricted riparian spaces (Fig. 1d).

Catchment and river basin managers continue to seek new solutions for improving water and ecological quality of surface waters worldwide. In the period since a previous collection on the multiple benefits of riparian buffer management (Stutter et al., 2012), it is perhaps the incorporation of structural

M. Stutter, The James Hutton Institute, Craigiebuckler, Aberdeen, AB15 8QH, UK; B Kronvang, Dep. of Bioscience, Aarhus Univ., Silkeborg, Denmark; D. Ó hUallacháin, Crops, Environment and Land Use, Teagasc, Wexford, Ireland; J Rozemeijer, Deltares, PO Box 85467, 3508 AL Utrecht, the Netherlands.

Abbreviations: DOC, dissolved organic carbon; EU, European Union; GHG, greenhouse gas; IBZ, integrated buffer zone; SOC, soil organic carbon; SRB, saturated riparian buffer; VBS, vegetated buffer strip. 

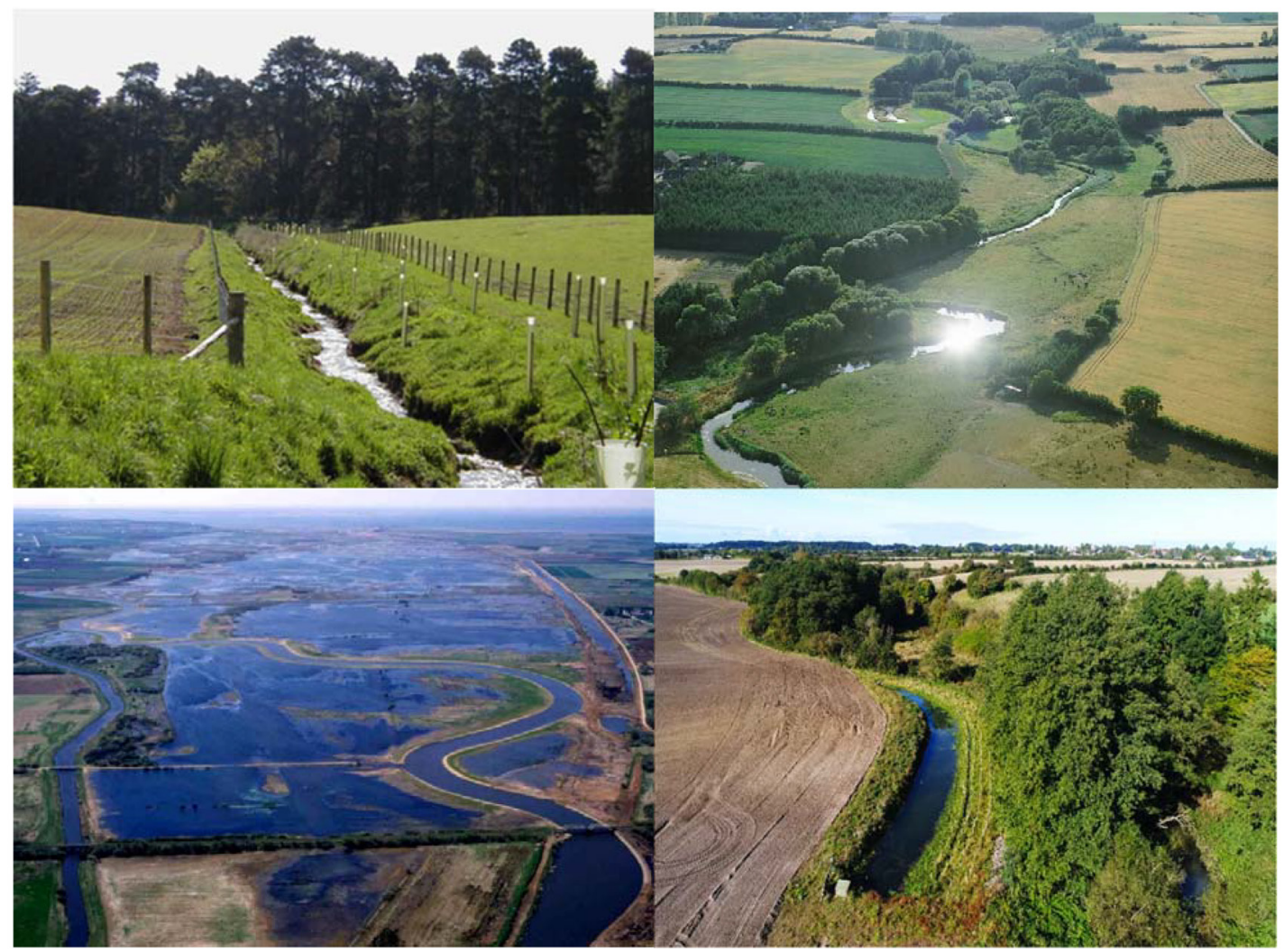

Fig. 1. A range of styles and scales of riparian management. (a) A narrow, fenced buffer zone within headwaters of the River Dee (northeastern Scotland) of regulatory compliance width but seeking additional benefits from tree planting on one bank (the sun-facing direction). (b) At a larger river scale, the River Odense (Funen, Denmark) surrounded by dry riparian buffers with grass and trees. This can be compared with (c) the rewetted riparian buffer to the remeandering of the River Skjern in 2002 (west Jutland, Denmark), one of the largest river and floodplain restoration projects in northwestern Europe. The space required for extensive riparian and channel restoration compares with (d) where buffer features enhancing riparian functions are incorporated into a 5- to 10-m-width design of stream buffer zone. These multifunctional zones can incorporate features such as ponds to intercept surface and subsurface runoff and enhance nutrient residence times in aquatic and tree-planted zones aside agricultural headwaters (Sillerup, Denmark).

components of buffers that has most developed (see also Mander et al., 2017). This includes restoring functions associated with saturated ground, trees, and other vegetation and enhancing biogeochemical processing with "treatment-train" elements such as bunds, mini-wetlands, and interruption of artificial drainage. Continuing research on management interventions restoring multiple functions of riparian buffers, and the basis of these functions in the natural environment, is required.

Globally, water quality objectives are still not being met in many countries, and eutrophication problems like harmful algal blooms and hypoxia are increasing in many developing regions like Southeast Asia (Strokal et al., 2016). In Europe, the European Union (EU) Water Framework Directive incorrectly projected widespread attainment of waterbody Good Ecological Status by the end of the first river basin planning round in 2015 (Voulvoulis et al., 2017). In the United States, loadings of $\mathrm{N}$ and $\mathrm{P}$ from agricultural catchments to lakes and coasts and overall success of mitigation actions are variable (Oelsner and Stets, 2019). In Australia, efforts continue to reverse greatly elevated river loadings of nutrients to protect coastal ecosystems (Brodie et al., 2017). Riparian buffers, as widely favored measures in river basin management, are often poorly targeted in seeking to address pollution. Therefore, it is timely to look again at riparian buffer management. Water quality remains a key driver of riparian management, but to maximize cross-sectoral, societal objectives, it must be combined with functions for biodiversity and climate adaptation as part of more integrated catchment management. Evidence needs remain for broader riparian management aspects (e.g., alternative buffer "productivity," enhancing aquatic ecosystem resilience) that will be persuasive to regulators and land managers in achieving more widespread uptake (e.g., Haddaway et al., 2018; discussed below). We need to recognize that riparian areas may provide space to incorporate new ecotechnologies (increasingly termed "green infrastructure") where "light" engineering principles enhance multiple functions (Fig. 1d).

Key aims for this new collection of papers were (i) to combine evidence of emerging designs of enhanced structural elements in riparian buffers and (ii) to provide an up-to-date synthesis of processes and functioning in natural and managed riparian buffers. This riparian management collection gathers primary investigations and reviews from leading groups researching riparian buffer functions to protect water quality, increase biodiversity, and adapt to climate change. The accompanying manuscripts comprise 16 papers from lead authors spanning eight countries of Europe and the United States, presented and discussed during a special session held at a Land Use and Water Quality 2017 conference (the Netherlands, May 2017; www.luwq2017. nl/special_sessions; Fraters et al., 2017) and supplemented by a targeted invitation drawing on US studies.

This synthesis is structured around the following priority topic areas, emphasizing the current state-of-the-art in research 
on these topics and concluding with recommendations for future research and implementation needs:

- Sediment, nutrient, and pesticide removal efficiency of traditional and saturated buffer strips.

- Enhancing the ecological quality of riparian buffer zones.

- New technologies applied as edge of field technologies for improving their nutrient retention.

- Reuse of nutrients and biomass from buffer strips.

\section{New Contribution of Knowledge to the Topic}

\section{Sediment, Nutrient, and Pesticide Removal Efficiency of Conventional and Saturated Buffer Strips}

Nitrogen and phosphorus are among the most important pressures on aquatic ecosystems, where excess inputs may deteriorate ecosystem integrity and/or threaten drinking water resources (Kronvang et al., 2005). Traditionally, riparian buffers are one of the most commonly applied nutrient management measures. Conventionally, vegetated buffer strips (VBSs) are established without additional management, using natural grass and herb vegetation with the aim to control sediment, particulate, and dissolved forms of $\mathrm{P}$, pesticides, and dissolved $\mathrm{N}$ losses to surface waters (Dorioz et al., 2006; Borin et al., 2010; UusiKämppä et al., 2012).

Riparian buffers can remove $\mathrm{NO}_{3}$, although their effectiveness in enhancing denitrification appears to be less than for intercepting sediment and particle-associated pollutants (Mayer et al., 2007). The review by Vidon et al. (2019) corroborates that riparian zones act as sinks for $\mathrm{N}$ in subsurface flow and total $\mathrm{P}$ in surface flow, but they also found inconsistent water quality benefits regarding soluble reactive $P$ in subsurface flow. However, the review highlights that riparian zones often exhibit higher greenhouse gas (GHG) emissions than sites immediately upland. The opposite was found by Davis et al. (2019), who observed lower $\mathrm{N}_{2} \mathrm{O}$ emissions in traditional and saturated buffers strips compared with the adjacent corn (Zea mays L.) fields in Iowa, USA. Given the importance of pollution trading between $\mathrm{N}$ reductions in waters and $\mathrm{N}$ atmospheric loading, this should be a topic for further research, since it was unclear whether higher GHG emissions were due to management or the location within the landscape.

In their meta-analysis across a great range in buffer widths, Valkama et al. (2019) highlighted that buffer zones were more effective at reducing $\mathrm{N}$ in groundwater $\left(70 \%\right.$ reduction in $\left.\mathrm{NO}_{3}\right)$ than in surface runoff ( $33 \%$ reduction). However, the meta-analysis found that buffering effectiveness was reduced with buffer zone age and was unrelated to width. In contrast, other studies in the current compilation support $\mathrm{NO}_{3}$ reduction effectiveness increasing with width (Dal Ferro et al., 2019; Jaynes and Isenhart, 2019). The latter studies examined narrower buffers and possibly identified minimum sizes (e.g., below $\sim 5 \mathrm{~m}$ where $\mathrm{N}$ interception became negligible compared with input loads). Pilon et al. (2019) showed that unfertilized, fenced buffer strips planted with trees reduced $\mathrm{N}$ losses by $54 \%, 10 \%$ more than unfenced grass buffer strips. Hence, gains for forested buffers were relatively small when considering the investments for tree planting and fencing. In terms of managing forested buffers, Rhoades (2019) found that riparian harvesting significantly increased dissolved organic $\mathrm{C}$ (DOC), total dissolved $\mathrm{N}$, and $\mathrm{NO}_{3}$ leaching when this harvesting was performed in beetle-infested stands (where $>80 \%$ of trees were already dead). However, these postharvest effects were mediated by rapid regeneration of herbaceous vegetation and aspen shoots.

The longer-term functioning of VBSs for storage of sediment and $\mathrm{P}$ has been questioned in the international literature, with the concern being that buffers may become a future $\mathrm{P}$ source due to decreasing soil $\mathrm{P}$ sorption capacities with age and P loading (Hoffmann et al., 2009; Stutter et al., 2009). In their study of a 57-yr-old unmanaged VBS, Habibiandehkordi et al. (2019) found significantly higher mean masses of sediment and P in surface soils at the border of the VBS $(6966 \mathrm{~kg}$ total $\mathrm{P} \mathrm{ha}^{-1}$ and $10702 \mathrm{Mg}$ sediment $\mathrm{ha}^{-1}$ ) than either $5 \mathrm{~m}$ upslope into the field (3956 kg total $\mathrm{P} \mathrm{ha}^{-1}$ and $5346 \mathrm{Mg}$ sediment ha ${ }^{-1}$ ) or $5 \mathrm{~m}$ into the VBS $\left(2776 \mathrm{~kg}\right.$ total $\mathrm{P} \mathrm{ha}^{-1}$ and $3992 \mathrm{Mg}$ sediment $\mathrm{ha}^{-1}$ ). They also found that surface soils at $5 \mathrm{~m}$ into the VBS had a significantly greater $P$ sorption capacity and a smaller degree of $P$ saturation than adjacent field soils, the latter attributed to $\mathrm{P}$ enrichment in the field resulting from manure or fertilizer application. Hille et al. (2019) quantified the effects of annual vegetation harvesting to deplete the accumulated pools of soil $\mathrm{P}$ as $\mathrm{P}$-enriched fines were trapped over years in the buffer. Habibiandehkordi et al. (2019) observed that the P saturation of VBS topsoil as compared with subsoil had increased as little as $\sim 11 \%$ over the 57 -yr period, and the authors concluded that their sites did not support the hypothesis of saturation of VBS topsoils with P. It would be advantageous to bring in knowledge of $\mathrm{P}$ sorption and saturation in different soil types that is well developed in the agronomic literature to support recommendations for reducing $\mathrm{P}$ in differing buffer soil matrices.

Conventional riparian buffers are designed so that many ecosystem services are associated with encouraging the action of dense vegetation to slow down uniform or concentrated surface flow and increase water infiltration. This reduction in flow velocity allows suspended sediment to be deposited, thereby decreasing transport of sediment, associated nutrients, and other contaminants within the buffer, particularly at the leading edge (Dillaha et al., 1989; Daniels and Gilliam, 1996; Stutter et al., 2012). Singh et al. (2019) showed that giant cane [Arundinaria gigantea (Walt. ) Muhl] was superior of other grass treatments in increasing water infiltration rates, controlling surface runoff volumes, reducing total suspended sediment and total $\mathrm{P}$ concentrations, and allowing residence time for biogeochemical processes within the VBS. However, these authors showed that dissolved reactive $\mathrm{P}$ concentrations in surface runoff were lowest in bare-ground treatment plots, highest in corn treatment plots, and intermediate in giant cane, Kentucky bluegrass (Poa pratensis L.), and orchardgrass (Dactylis glomerata L.) plots. This suggests interactions with other vegetation processes and that biomass harvesting may help avoid dissolved P losses from VBSs (as also addressed by Hille et al., 2019).

Dal Ferro et al. (2019) found that 6-m buffer strips achieved reductions in total suspended solids (64\%), total P (31\%), and herbicides (45-98\%), whereas 3-m buffers were less effective and even enhanced some pollutant losses to watercourses relative to controls. Subsidies for these buffers were for management of buffers for trees. However, since the buffers also enhanced water quality, the authors recommended restructuring the subsidies attained to be increased when multiple ecosystem services were 
achieved. O'Callaghan et al. (2019) showed that for sediment, livestock poaching causes localized bank damage, in turn leading to further erosion, and that direct cattle access to watercourses resuspends bed sediments. They found that riparian fencing has implications for management in supplying alternative watering for cattle (in terms of their funding and maintenance) for animal welfare (removing access to tree shade).

\section{Diffuse Pollution Effectiveness with Enhanced Buffer Management}

Several studies explored implications of more active management of the buffer space for diffuse pollution functioning. Hénault-Ethier et al. (2019) found that there was no significant difference in the buffering capacity (for N, P, or K) between 3-mwide riparian zones planted with willow (Salix spp., regardless of density) and riparian zones with naturally regenerated herbaceous cover. Season strongly affected the buffering ability of the riparian buffer zones, with the highest efficiency occurring when water entering the zone had the highest nutrient concentrations (immediately after sowing and fertilizer application). The study concluded that narrow riparian buffer zones (i.e., $3 \mathrm{~m}$ ) with various management regimes (without additional measures) were insufficient to protect streams from excess nutrients. Zak et al. (2019) discussed designs of integrated buffer zones (IBZs) across northwestern Europe that aim to improve nutrient retention efficiencies in smaller buffer widths. The incorporation of structural elements of mini-wetlands and trees gave an average $\mathrm{NO}_{3}$ removal efficiency of 23 to $37 \%$ and an average total $\mathrm{P}$ removal efficiency of 18 to $52 \%$. The study concluded that removal and retention of sediment in the IBZ was 0.5 to $1.3 \mathrm{~kg} \mathrm{~m}^{-2}$.

Enhanced management is required to tackle subsurface transfer pathways for nutrients. Jaynes and Isenhart (2019) showed all six sites of their designs of saturated riparian buffers (SRBs) to be effective in removing $\mathrm{NO}_{3}$ from the tile drainage water entering the SRB. The annual $\mathrm{N}$ removal effectiveness (measured as the $\mathrm{NO}_{3}$ removed in $\mathrm{SRB}$ divided by the $\mathrm{NO}_{3}$ load draining from the field) ranged from 8 to $84 \%$. This corresponds to an average removal rate of $40 \mathrm{mg} \mathrm{N} \mathrm{m}^{-3} \mathrm{~d}^{-1}$ (range 4-164 $\mathrm{mg} \mathrm{N} \mathrm{m}^{-3} \mathrm{~d}^{-1}$ ). The design of SRBs is a new type of intervention for subsurface pathways and removal effectiveness for $\mathrm{NO}_{3}$ was found to depend on the buffer age. The SRBs constructed on "old" VBSs performed at nearly twice the $\mathrm{NO}_{3}$ removal efficiency of SRBs newly constructed into new buffer space and seeded with perennial vegetation. Such a finding is important, since catchment and field managers want to maximize nutrient removal effectiveness immediately after the installation of edge-of-field mitigation measures.

Unless managed correctly, incomplete denitrification can result in negative effects from buffers in terms of gaseous losses. Groh et al. (2019) found that denitrification rates measured in the SRBs established on 20-yr-old riparian buffers could explain 48 and $77 \%$ of the total $\mathrm{NO}_{3}$ removal in the SRB. Conversely, this was reduced to 8 and $36 \%$ for the SRBs established on the 3 -yr-old riparian buffer and only $4 \%$ in SRBs on newly established buffer space. The authors strongly advocated promoting high groundwater levels to use the entire soil column for removal of $\mathrm{NO}_{3}$ in $\mathrm{SRBs}$, especially the topsoil ( 0 - to 20-cm depth) where denitrification rates were greatest (median $=3.7-14.1 \mathrm{mg} \mathrm{N}$ $\mathrm{m}^{-3} \mathrm{~d}^{-1}$ ). Including the topsoil would increase the cumulative denitrification rates to $>100 \%$ for the SRB established within a 20 -yr-old riparian buffer to $78 \%$ for the SRB established in the 3-yr-old buffer and 39\% for the SRB in the 1-yr-old buffer. Although greater denitrification rates occur in SRBs, Davis et al. (2019) found that such SRBs did not result in increased $\mathrm{N}_{2} \mathrm{O}$ emissions compared with traditional buffer strips and that both saturated and traditional buffer strips had lower $\mathrm{N}_{2} \mathrm{O}$ emissions than fertilized cropland. Potentially, this means that suitable conditions may lead to complete denitrification to $\mathrm{N}_{2}$. However, since Vidon et al. (2019) reported higher $\mathrm{N}_{2} \mathrm{O}$ rates for buffers than adjacent cropland, this suggests that conditions, and hence degree of denitrification, widely vary.

\section{Enhancing the Ecological Value of Riparian Buffer Zones Management of Riparian Buffer Zone Biodiversity}

Biodiversity has undergone significant declines throughout Europe in recent decades, particularly where intensification of agriculture has resulted in dramatic losses of biodiversity (Robinson and Sutherland, 2002; Tscharntke et al., 2005). There is an implicit assumption of the delivery of ecosystem services related to riparian buffer functions, but considerable uncertainty in evidence remains as to how to achieve and assess these (Stutter et al., 2012). Several papers in this collection show that appropriate management of riparian buffers can enhance the delivery of multiple ecosystem services (Brown et al., 2019; Dal Ferro et al., 2019; Hille et al., 2019; Singh et al., 2019; Zak et al., 2019), along with improving the ecological value of the riparian zones and the adjacent aquatic habitat. Zak et al. (2019) showed that IBZ designs, encompassing tree and mini-wetland areas in relatively narrow margins, can act as a habitat for a diverse range of species, including species of conservation concern. These authors showed that such management of riparian habitats can enhance invertebrates, including important biocontrol groups such as carabids, syrphids, and parasitoids, relative to alternatively managed field margins. This supports other research showing that increasing the heterogeneity, connectivity, and abundance of wildlife habitats have a positive influence on the abundance and richness of a variety of species (Pollock et al., 1998; Benton et al., 2003; Sabo et al., 2005). In turn, this benefits habitat quality and ecosystem services in field (Smart et al., 2006; Ricketts et al., 2008; Dybkjær et al., 2012) and instream (Harrison and Harris, 2002). Although issues of weed transfer and harboring of crop pests from the buffer require management, in their review of the effects of riparian grazing impacts and benefits of access management, O'Callaghan et al. (2019) make the important point that catchment-wide strategies may have a bigger influence on aquatic and riparian ecology than localized riparian management.

The botanical composition of the riparian zone will not only influence the species diversity but also the delivery of additional ecosystem services. Poorly managed riparian buffers can become constrained, with little heterogeneity in vegetation structure and habitat type along stream reaches. Historical prescriptions for riparian zone management often recommended fencing riparian margins, with little subsequent additional management. O'Callaghan et al. (2019) highlighted that there were divergent responses in relation to the impact of riparian fencing on aquatic and terrestrial biodiversity. McCracken et 
al. (2012) stressed that simply fencing riparian margins can never solely redress biodiversity declines.

Several studies in this collection highlight the age of the riparian zone as an important factor in relation to the delivery of ecosystems services, including biodiversity benefits (Groh et al., 2019; Jaynes and Isenhart, 2019; O'Callaghan et al., 2019; Valkama et al., 2019). Often, functions took several years to develop, associated with maturing vegetation and habitat development. These results highlight potential limitations associated with shorter-term policy cycles that support riparian buffer installation and their ongoing management. For example, EU agrienvironmental support has $\sim 6$-yr funding cycles, whereas ecosystem benefits may not become apparent until after a decade of commitment. Additionally, divergent policy recommendations such as those that support agricultural improvement practices, including drainage, stream channelization, and modification of natural riparian systems, can also significantly affect the habitat quality of riparian buffers and adjacent watercourses and ideally should be considered together at a system level.

\section{Synergies and Tradeoffs between Different Ecosystem Services}

It is important to recognize that the appropriate management of vegetated riparian zones can result in the simultaneous delivery of multiple ecosystem services. Singh et al. (2019) highlighted that the inclusion of giant cane in riparian buffer zones had significant water quality benefits, along with biodiversity benefits, as canebrakes are an important but declining habitat for a variety of species. Zak et al. (2019) demonstrated the delivery of multiple services with IBZs, incorporating aquatic features and associated hydrological processes that helped improve water quality while supporting wetland biodiversity. This supports work by Madden et al. (2015) showing that restoration of hydrologic processes within riparian zones enhances riparian or wetland specialist species. Such saturated buffer zones can also play an important role in $\mathrm{NO}_{3}$ removal (Jaynes and Isenhart, 2019). The interactions of vegetation and soil organic matter for $\mathrm{N}$ cycling were discussed in the primary studies by Groh et al. (2019) and Jaynes and Isenhart (2019), in terms of a more established vegetated buffer facilitating stronger potential runoff $\mathrm{NO}_{3}$ reductions. However, the metadata review by Valkama et al. (2019) found limited effects of vegetation type on buffer $\mathrm{N}$ retention.

Potential conflicts and compromises should be recognized; the delivery of one ecosystem service may come at the expense of another. Hille et al. (2019) highlighted that harvesting riparian vegetation was an effective strategy for reducing P leaching from buffers zones. However, the implications of this management prescription on biodiversity require further research. Harvesting management is also important where buffer zone vegetation comprises trees (Dal Ferro et al., 2019; Zak et al., 2019; Rhoades, 2019) or other biomass (Brown et al., 2019). These issues highlight the important role that clear, robust agricultural and environmental policy can play a part in influencing management and determining the effectiveness of riparian buffer zones. This topic is particularly topical in Europe, as the latest revision to the EU's overarching agricultural rules and payments system (Common Agricultural Policy) strives to place greater value on "nonproductive" habitats such as buffer zones and, in turn, broaden the scope for payments for wider ecosystem services associated with them.

\section{New Technologies Applied at the Edge of Fields for Improving their Nutrient Retention}

In areas with intensive agriculture and high land prices, farmers are often unwilling to dedicate land for buffer strips or purification wetlands. In such circumstances, concentrating edge-of-field technologies in the relatively narrow riparian spaces can be used to purify agricultural drainage water. Phosphorus and nitrogen can be captured in reactive barriers from agricultural drainage via groundwater, tile drains, and/or overland flowpaths. Dissolved P can be adsorbed to Fe-coated sands or Fe slags in edge-of-field reactors or trenches. Nitrate losses can be prevented by enhancing denitrification, for example, in edge-of-field woodchip reactors. Previous studies have suggested that such edge-of-field nutrient retention technologies could reduce $\mathrm{P}$ loads from agricultural drainage by 80 to 95\% (Groenenberg et al., 2013; Penn et al., 2014), reduce N loads by 30 to $80 \%$ (Christianson et al., 2012), and have potential for uptake of pesticides (Rodríguez-Cruz et al., 2011).

Jansen et al. (2019) tested denitrification over $3 \mathrm{yr}$ in in situ edge-of-field bioreactors, comprising organic matter substrates of either woodchip or a system of ethanol dosing to drive microbial $\mathrm{N}$ removal. The study addresses optimizing such systems for $\mathrm{N}$ reduction efficiencies and minimization of side effects. Although the principles of bioreactors are well known, their field operation needs to be examined in terms of cost efficiency, robustness, and optimizing critical factors of organic matter supply rate, redox, temperature, and flow. Passive dosing techniques were found to be simple, low energy, and require little maintenance. Ethanol dosing led to up to $95 \% \mathrm{~N}$ removal (at 0.1 -d hydraulic retention time) compared with $80 \%$ in the first year for woodchips $(5-d$ hydraulic retention time).

Within the same study, subsurface drain tubes at the 1- to 1.2-m soil depth were enveloped with woodchip and sand (with or without beet pulp [Beta vulgaris L.]) mixtures. For woodchipenveloped drains, the denitrification efficiency was reduced with declines in the DOC supply rate in the second and third years of installation (to zero with beet pulp, 30\% woodchip only) but could be increased by digging the drain system deeper into the soil $(60 \%$, where redox was more favorable). The ethanol dosing system comprised a 700-L reactor with baffled flow in contact with tubing diffusing ethanol. The ethanol was proposed to reduce side effects from woodchip in terms of released $\mathrm{NO}_{2}$ and chemical $\mathrm{O}_{2}$ demand (incomplete $\mathrm{N}$ removal and DOC uptake, respectively), but lower efficiencies for total dissolved $\mathrm{N}$ than for $\mathrm{NO}_{3}$ indicated $\mathrm{NO}_{2}$ losses. Given their results, Jansen et al. (2019) suggest that a combination system (not tested) with woodchip and ethanol could optimize complete denitrification and minimize side effects. This system may be completed with an additional down-system $P$ filter to prevent the release of $P$ from the woodchip system at low redox potentials.

In addition to edge-of-field bioreactors, several structural design elements for buffers are reported in this collection that aim to enhance the attainment of biogeochemical processing within the buffer strip space to improve their effectiveness in nutrient retention. Two examples are reported by Jaynes and Isenhart (2019) and Zak et al. (2019). Both the types of 
interventions described in these studies apply simple principles of engineering to modify flowpaths, increase water residence time, and expose nutrient-enriched waters to enhanced natural attenuation processes within the treatment system. Jaynes and Isenhart (2019) studied the performance of six SRBs in Iowa, USA, where control box structures were incorporated to elevate (without power) subsurface drainage pathways to irrigate onto topsoils where naturally greater soil organic C (SOC) than at subsoil drainage depths facilitated denitrification. The effective width requirement of these SRBs ranged between 4 and $24 \mathrm{~m}$ where topsoils had slow permeability and SOC $\geq 0.75 \%$ in at least the top $1 \mathrm{~m}$. The cost efficiency of SRBs was calculated as $\sim U S \$ 3 \mathrm{~kg}^{-1} \mathrm{~N}$ removed, which is competitive with other fieldedge denitrification bioreactors and constructed wetlands.

A different design of wet buffer system was reported by Zak et al. (2019), the IBZ design for the provision of a variety of different ecosystem services as demonstrated across a network of sites in three northern European countries. The IBZ design includes elements of a narrow linear wetland system, into which subsurface drain lines are intentionally broken, allowing suspended particles to settle, and a more traditional infiltration zone with tree planting to enhance nutrient uptake using a "bioreactive" root zone (atmosphere to root C "pump" stimulating microbes and longterm vegetation uptake). As in the example by Jaynes and Isenhart (2019), the IBZ design (Zak et al., 2019) uses simple engineering principles to match wetland and filter-bed sizing to landscape context and loading and give simple control structures for water spills. The effectiveness of this system is discussed against the overall aim of increasing residence times of water and contaminants to maximize natural process attenuation alongside providing wider, multiple benefits. Such landscape interventions share commonalities with developments in natural flood management, where designs seek to provide temporary water storage in bunds (wood, earth, and stone) or cascades of ponds to reduce flood peaks. Shared intended outcomes include slowing fast runoff and providing filtering potential for sediments. Many engineering principles are similar, and the riparian space is often targeted.

\section{Can We Reuse Nutrients and Biomass from Buffer Zones?}

The question of the reuse of nutrients and biomass from buffer zones has relevance to the technical functioning of the buffers, the maintenance regime, and in persuasion for buffer space via compensating for productivity losses from cropping on the field space given to the buffer (Christen and Dalgaard, 2013). At one extreme, the buffer zone's productivity could be envisaged as part of a seminatural space in otherwise agricultural landscapes where foraging and hunting of wild food could take place. At the opposite extreme, the buffer productivity could be from a hybridized fast-growing willow or grass within a treatment bed designed to maximize nutrient uptake and growth into bioenergy cropping. Examples of both exist already in landscapes, and it is likely that, depending on the viewpoint, either could be perceived as compensating for lost productivity on land taken for the buffer zone. This could be either as direct financial return (e.g., bioenergy cropping), or public goods potentially subsidized by public money (e.g., recreational, hunter-gathering services). The question of nutrient and biomass reuse has immediate relevance in two areas of developing practices: the generation of a wood-fuel crop as a supplement to farm economics, and the removal of vegetation and stored nutrients that facilitates the continuing nutrient sink ability of the buffer zone. Several studies in this riparian management collection deal directly with these aspects and, in these and more widely across all papers, strong interactions of nutrient and biomass removal with buffer management are considered.

\section{Biomass Removal to Subsidize Farm Income}

Dal Ferro et al. (2019) studied a system where trees were grown for firewood in 3- and 6-m buffers adjacent to arable land in an area of traditional farming practice in Italy. There was a motivation to also achieve multiple benefits for wood fuel production, as well as reducing suspended sediment, nutrient runoff, and pesticide spray drift. Designs of alternating Viburnum shrubs between plane trees were used with grass understory in three designs: a 3-m buffer single row, and 6-mwide single and double rows of trees. Coppicing was done every 6 to $7 \mathrm{yr}$ by hand with chainsaws. The authors reported 33 to $52 \%$ greater wood yields attained in two-row than one-row systems, but $20 \%$ greater yield for trees closer to the field (1.5 $\mathrm{m})$ than further $(4.5 \mathrm{~m})$, indicating nutrient benefits associated with preferential nutrient trapping at the upslope buffer edge. Returns of 0.2 to $0.7 \mathrm{t}$ dry matter per linear meter of buffer were insufficient to provide appreciable profit to farmers considering lost revenue of field crop and subsidies. The costs of management and firewood processing were only covered for sale when at the best well-seasoned quality price, even when factoring in EU environmental stewardship payments received for such buffers. Simple wood drying treatments were studied that increased profitability. This paper did not consider the $\mathrm{N}$ and $\mathrm{P}$ yields of the biomass removal, but this would be appreciable given the good overall biomass yields.

Other studies in the collection offer data or discussion on the nutrient offtakes associated with the timber yields. Zak et al. (2019) described that, for the IBZ design planted with willow, the standing biomass yields per hectare (after $\sim 2$ yr growth) was 17 to $40 \mathrm{t}$ dry matter, with 8 to $19 \mathrm{t} \mathrm{C}, 201$ to $458 \mathrm{~kg} \mathrm{~N}$, and 30 to $70 \mathrm{~kg}$ P. Hénault-Ethier et al. (2019) assessed whether the inclusion of fast-growing willow in riparian buffer zones could improve the nutrient retention of the zone. They cited other work that indicated that willow wood harvested after $3 \mathrm{yr}$ from riparian zones allowed for permanent annual export of 116 to $447 \mathrm{~kg} \mathrm{~N} \mathrm{ha}^{-1}, 62$ to $239 \mathrm{~kg} \mathrm{~K} \mathrm{ha}^{-1}$, and 23 to $86 \mathrm{~kg} \mathrm{P} \mathrm{ha}^{-1}$.

There are management issues associated with cropping trees in the buffers. Zak et al. (2019) noted that although production of biomass can provide financial incentives for land managers, harvesting of small fragmented areas such as IBZs may be challenging due to machinery access difficulties. It was earlier also noted by Ferrarini et al. (2017) that the limited operating space for machinery was an issue for bioenergy buffers (as opposed to larger-scale plantations) and that spatial fragmentation across and between farms added to biomass handling and processing costs. This aspect of mechanized harvesting was also considered by Rhoades (2019) in managing mature forest dead wood in a 30-m-wide stream buffer zone where either specialist machinery (beam cutters) or labor-intensive manual cutting and winching out were used to protect the stream-side zone. The interactions of harvesting with biodiversity have been less studied here and remain a gap in setting management guidance. 
Biomass Cropping for Nutrient Removal and Reuse with Implications for Maintaining Buffer Functions

Hille et al. (2019) addressed the maintenance of buffer strips as a crucial factor governing their longer-term nutrient retention effectiveness. Without maintenance, buffer strips are known to become a potential source of nutrients rather than a sink, especially for P (Dorioz et al., 2006; Stutter et al., 2009), hence maintenance should prevent the accumulation of nutrients in the buffer strip. Hille et al. (2019) studied achieving this via harvesting treatments of grasses and herbs over $2 \mathrm{yr}$ compared with an extreme alternative of topsoil removal in 10- to 12 -m buffer strips. The authors used the reduction in soil P leaching concentrations to appropriate streamwater quality thresholds as their metric of assessment. Annual vegetation harvesting was an effective buffer strip management approach to reduce modeled long-term $P$ leaching. One harvest per year was considered most cost effective, as multiple harvests did not have an extra effect. Topsoil removal was not considered an effective alternative strategy for achieving $\mathrm{P}$ leaching targets since the physical and ecological stability of the soil is disrupted. However, topsoil removal may be appropriate when the soils are disrupted anyway (e.g., during the construction phase of the buffer strips). Hille et al. (2019) did not consider the reuse options for the material. They did consider that the effort was large in achieving the vegetation offtake by manual cutting and removal and whether light, managed grazing could be considered, or production of a specialist hay crop. Considering arguments by O'Callaghan et al. (2019), cattle present risks in riparian areas, and maybe periodic grazing could be achieved better with sheep.

Habibiandehkordi et al. (2019) studied how effective Canadian buffer strips were in controlling P exports according to levels of $\mathrm{P}$ saturation attained in the buffers. Although their investigated buffers were not sufficiently $\mathrm{P}$ saturated to pose major leaching risks, they proposed that cutting and removal of vegetation could be a useful strategy to remove $\mathrm{P}$ for delaying possible $\mathrm{P}$ saturation and losses in the long term. This was considered especially useful to minimize possible $\mathrm{P}$ remobilization associated with vegetation senescence, especially in cold climate zones.

Building on studies that advocate vegetation removal as critical to maintaining buffer functions, Brown et al. (2019) considered that the biomass harvested from buffer strips may be reused to provide adjacent cropped soils with additional nutrients and organic matter. These authors looked at the $\mathrm{N}$ and $\mathrm{P}$ content of different types of buffer strip plant species and at their ability to promote yields and the nutrition of spring barley (Hordeum vulgare L.). Biomass was harvested from two Scottish buffer strips and applied as green manure in a controlled environment to spring barley in plastic pots. In addition, the green manure was combined with inorganic $\mathrm{P}, \mathrm{N}$, or $\mathrm{N}-\mathrm{P}-\mathrm{K}$ fertilizer. The experiments showed that the buffer strip biomass did not cause better crop growth than the unfertilized crops. However, when used in combination with inorganic fertilizers, the buffer strip biomass did have a positive effect on spring barley growth. The different buffer strip plant types differed in their P contents but did not significantly differ in their effect on spring barley growth. Under the experimental conditions, there was no need to select specific plant species in the buffer zones to promote the quality of the green manure from the harvested biomass. Using biomass from buffer strips as green manure cannot replace inorganic fertilizer use in arable farming. However, the combination of buffer strip biomass with inorganic fertilizer that had positive effects on crop growth is a more realistic scenario given the typical area ratios of buffers to fields that limits the biomass field application rate.

The collective evidence from the new studies here suggests that, within constraints, we can and should reuse nutrients and biomass from buffers. The harvesting of nutrients is vital to maintain key buffer functions such as long-term nutrient retention. Since this must necessarily become part of a buffer's management regime, this needs to be promoted with guidance to maximize benefits versus the effort and achieve this with sensitivity to the stream-side protection zone and biodiversity. Recent work by Styles et al. (2016) and Ferrarini et al. (2017) support that payments for ecosystem services provided by bioenergy buffers will improve the economics of such systems. Brown et al. (2019) showed the partial chemical fertilizer P replacement achievable via green manure returns of vegetation-harvested nutrients from buffers to cultivated areas; this may suit some specialized farming systems such as organic farming or farms in developing countries.

\section{Riparian Management Survey}

In addition to the papers arising, the 2017 conference session on multifunctionality of buffer strips for enhancing biodiversity and for reducing edge of field losses of sediment, nutrients, and pesticides provided an opportunity for a survey among the international group of experts (Fig. 2). Respondents $(n=14)$ answered two questions:

1. To what extent are a range of perceived benefits from riparian buffers (given as eight options) actively sought and managed for?

2. What is the current level of evidence regarding the same list of benefits?

The average scores for Question 1 (Fig. 2a) show that "terrestrial biodiversity" and "channel morphological improvements" were considered primary buffer strip benefits actively sought and managed for. Interestingly, low scores were given to "interruption of sediment and nutrients by surface flow path" and "interruption of nutrients by subsurface flow paths." These results indicate that local ecological benefits of buffer strips drive contemporary buffer implementation among the respondents' countries and organizational objectives. Question 2 (Fig. 2b) suggests that the evidence for "soil C storage" was considered the strongest, with "recreation/cultural benefits" considered the weakest. "Channel morphological improvement" was high on the list of benefits sought and managed for but low on evidence levels and may be considered a future research need. The lack of evidence on "interruption of nutrients by subsurface flow paths" was notable, despite a lack of perceived importance compared with habitat objectives for the attendees.

\section{Future Research and Implementation Requirements \\ Future Research Needs}

The current collection addresses an intervention gradient across natural riparian processes to increasingly designed technical riparian management options, seeking evidence of functions relating to diffuse pollution pathways and cycling, ecological 


\section{(a) Buffer strip benefits sought and managed for}

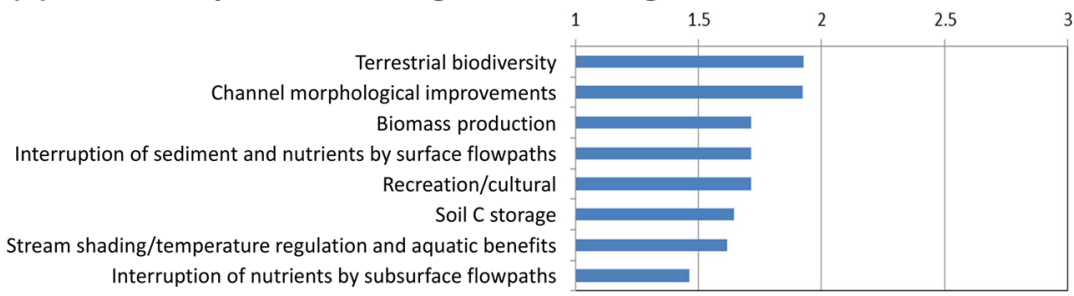

\section{(b) Buffer strip benefits levels of evidence}

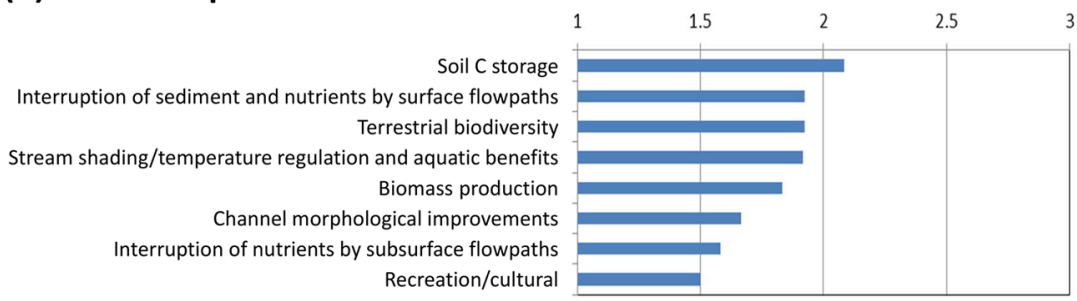

Fig. 2. Conference survey results (average scores from 1 [low] to 3 [high]) regarding (a) what riparian buffer strip benefits were actively sought and managed for in their countries, and (b) what respondents considered was the level of evidence for the same benefits. Our 14 respondents came from Europe, the United States (Vermont), and Uruguay. The European respondents were from Denmark $(n=4)$, the Netherlands $(n=2)$, Belgium, Germany, Ireland, Norway, Scotland, and Sweden (all $n=1)$. Respondents were active in science $(n=11)$, policy $(n=3)$, or consultancy $(n=2)$, where two respondents noted activity in science and policy. Error bars (not shown) were of consistent magnitude between categories.

Table 1. A summary across the four topics of this current collection as to areas of strong evidence versus weaker evidence, or a lack of consensus.

\begin{tabular}{lll}
\hline Topic area $\quad$ Aspects with strong evidence and consensus & Aspects with only weak or developing evidence, or lack \\
of consensus
\end{tabular}

Sediment, nutrient, and pesticide Benefits of conventional vegetated buffer strip (VBS) removal efficiency of traditional and saturated buffer strips

Enhancing the ecological quality of riparian buffer zones

New technologies applied as edge-of-field technologies for improving their nutrient retention

Reuse of nutrients and biomass from buffer strips
Benefits of conventional vegetated buffer strip (VBS)
designs for trapping sediment- and particle-associated pollution in (nonconvergent, nonextreme) surface

Saturated buffers are becoming recognized for their role in denitrification of subsurface $\mathrm{N}$, but this requires enough soil organic C (e.g., found in topsoils of established, vegetated buffers).

Very narrow buffers $(<3-4 \mathrm{~m})$ serve only as a physical border and are limited in contaminant retention and cycling processes (especially when subsurface preferential pathways exist).

Managing cattle access to riparian areas benefits sediment and microbial water quality.

Managing riparian cattle access enhances aquatic invertebrates.

Buffers with designed diffuse pollution functions have potential for multiple ecosystem habitat benefits (vegetation, invertebrates), especially associated with a diversity of wet and dry features.

Methods promoting denitrification are readily achievable particularly in saturated buffers. However, tile drainage requires manipulation to intercept and raise flows and promote treatment residence time.

Simple, engineered features can improve sediment retention and counter uncertainties of more variable particle retention with conventional VBSs associated with extreme events and convergent flows.

Evidence for yields of herbaceous and woody biomass are becoming well documented. Herbaceous and woody vegetation can make contributions to longerterm $\mathrm{N}$ and $\mathrm{P}$ retention but have differing harvesting commitments. runoff are well documented.
Inconsistent capture and retention of soluble $\mathrm{P}$ is shown in subsurface flows through buffers. Cycling processes for $P$ in soils and vegetation require further work.

The conditions under which legacy $P$ accumulation initiates problematic $P$ leaching requires research.

Nitrogen greenhouse gas (GHG) emission fluxes seem to vary between the buffer and the field. Hence, the controlling mechanisms for this and how to promote more complete denitrification need further research.

Generally, interactions and their mechanisms between terrestrial and aquatic habitats are poorly developed. Channel morphological improvements associated with riparian buffer management require specific study.

Catchment-wide coordinated management seems likely to maximize multiple ecosystem service goals from buffers (especially habitat) but requires further research into better practice.

Tradeoffs with designed denitrification buffers using labile $\mathrm{C}$ additions require validation against the negative effects of N GHG emissions. Combinations of the most appropriate $\mathrm{C}$ sources needs research for inducing more complete denitrification while maintaining low pollution in water outflows.

Technical additions for $\mathrm{P}$ sorption require further development, and integration of $\mathrm{N}$ and $\mathrm{P}$ reduction methods is seldom addressed together.

Biodiversity implications of biomass harvesting actions need to be assessed.

Economic benefits of harvesting seem marginal and should be evaluated more widely.

Nutrient reuse on cultivated fields is a new topic and should be examined as part of integrated nutrient management plans, especially if buffer vegetation cutting is to be promoted for nutrient mining purposes. 
functioning, and biomass as part of multiple benefits appraisal. Our synthesis provides an updated insight as to what is strongly evidenced versus weakly evidenced, or in disagreement, among the four topic areas of this collection (summarized in Table 1).

Natural riparian areas have many structural attributes that have become degraded in intensively farmed and developed landscapes (McCracken et al., 2012; Stutter et al., 2012). Collective studies across management gradients are required to understand what functions and benefits must be enhanced in managed buffers. We have drawn on three review and metadata studies and 13 primary investigations conducted in the United States $(n=6)$, Denmark ( $n$ $=2$ ), Canada, the United Kingdom, Sweden, the Netherlands, and Italy $(n=1)$. The buffer widths addressed in primary studies had a mean of $16 \mathrm{~m}$ (range $1-35 \mathrm{~m}$ ) with an average duration of active study period of $4.6 \mathrm{yr}$ (range $<1-15 \mathrm{yr}$ ).

A strong need for scientific evidence for riparian buffer functioning comes from the continuous need to evaluate environmental benefits of the riparian corridor against production losses for the farmer, especially in intensive agricultural regions. In Denmark, for example, a repeal of the mandatory introduction of 10-m buffer strips along all streams occurred after several years due to evidence needs and political change (Thorsøe et al., 2017). The main counterarguments from Danish farmers against the mandatory rules were that (i) such buffers should only be implemented in a targeted way, and (ii) several international studies document that the $\mathrm{NO}_{3}$ retention potential within artificially drained lands was insignificant when tile drain water was not filtered by the buffer zone, hence the environmental benefit is only associated with reduced $\mathrm{NO}_{3}$ leaching in the buffer zone itself.

Table 2 provides a summary of recent buffer evidence mapping by Haddaway et al. (2018). We filtered the database entries to riparian buffers only (excluding in-field buffers). In North America, the evidence was dominated by $\mathrm{N}$ research for coastal receiving waters (with $\mathrm{P}$ considered less and generally for lake receiving waters) and with pesticides and terrestrial habitat moderately addressed. Research in Europe, Australia, and New Zealand addressed N, P, and terrestrial habitat equally. Interestingly, sediment seemed less of a focus, few studies addressed aquatic biodiversity, and except for Australian and New Zealand studies, biomass yields were poorly evidenced. Haddaway et al. (2018) highlighted 10 research gaps, of which seven are addressed directly by the current synthesis, namely:

- What role can vegetated strips play in climate regulation?

- What are the impacts of vegetated strips on aquatic (and semiaquatic) biodiversity?

- What are the long-term (>2-yr) impacts of VBSs and how do impacts vary over time and season?

- What are the impacts of harvesting strip vegetation on all outcomes?
- What is the role for the vegetated strip in fiber and fuel production in a circular bioeconomy?

- What characteristics improve multiple outcomes in multiuse strips?

- To what extent does the implementation of multiple interventions targeting different outcomes lead to synergies or conflicts?

However, the current collection does not address the further three research gaps identified by Haddaway et al. (2018), and these remain outstanding:

- What are the possible cultural ecosystem services?

- What is the relationship between pests and pest predators in buffers on crop yields and weed seed banks in field?

- What are the impacts of buffers on all outcomes from underrepresented countries (eastern Europe, Russia, Asia, and South America)?

In general, the interactions of managed (i.e., nonnatural) riparian buffers with aquatic habitats are not well studied. Stability of stream banks, erosion, and cattle access impacts on aquatic conditions and ecology were addressed in the current collection through the review and primary studies on cattle access (O'Callaghan et al., 2019; Pilon et al., 2019). The assessment of benefits for the IBZ designs (Zak et al., 2019) also reported on aquatic ecology of the incorporated mini-wetlands. A gap remains to evaluate the influence of a range of restored natural riparian to designed buffer conditions on ecologically relevant conditions of morphology, bank erosion, and water temperature, as well as directly of aquatic ecological communities across trophic levels. Also, how riparian management contributes to climate regulation has been only indirectly addressed here; although SOC sequestration has not been directly assessed, several studies have reported SOC concentrations, including comparison of SOC stocks with C stocks of aboveground biomass. In addition, soil-atmospheric interactions have been studied in terms of N GHGs emissions, and climate adaptation has been raised in terms of buffer features acting to control fast runoff as part of flood management.

Haddaway et al. (2018) also recognized research gaps in terms of the impacts of harvesting strip vegetation for a range of outcomes, as well as the role for this biomass in a circular bioeconomy. A subset of papers in this collection highlight a need for even narrow buffer strips to be managed to remove biomass and nutrients for many purposes, including avoiding legacy stores of nutrients close to waterbodies. This is important for developing long-term sinks and offtake mechanisms for $\mathrm{P}$, yet the conditions where $\mathrm{P}$ buildup becomes problematic for triggering leaching losses are shown to be variable. This soluble P buffering function is important for US receiving waters known to be P limited (Schindler et al., 2016) and in Europe, where P is increasingly implicated in water quality compliance failures. The effects of

Table 2. Overview table of riparian buffer study topics from boreal-temperate climates described in a recent evidence mapping study by Haddaway et al. (2018). Percentage values indicate the distribution of topics within studies (potentially multiple topics per study).

\begin{tabular}{|c|c|c|c|c|c|c|c|c|}
\hline \multirow{2}{*}{ Region } & \multirow{2}{*}{$\begin{array}{c}\text { No. of } \\
\text { studies }\end{array}$} & \multicolumn{2}{|c|}{ Biodiversity } & \multirow{2}{*}{$\mathrm{N}$} & \multirow{2}{*}{$\mathbf{P}$} & \multirow{2}{*}{ Sediment } & \multirow{2}{*}{ Pesticides } & \multirow{2}{*}{$\begin{array}{c}\text { Biomass } \\
\text { yield }\end{array}$} \\
\hline & & Terrestrial & Aquatic & & & & & \\
\hline & & & & -9 & $\mathrm{umb}$ & udies & 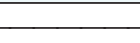 & - \\
\hline North America & 73 & 23 & 9 & 51 & 25 & 15 & 27 & 3 \\
\hline Europe & 18 & 37 & 5 & 53 & 42 & 11 & 5 & 5 \\
\hline Australia \& New Zealand & 5 & 40 & 5 & 60 & 60 & 0 & 20 & 20 \\
\hline
\end{tabular}


different vegetation management regimes need further evidence across a range of outcomes. Several studies here have dealt specifically with trees as elements of multipurpose buffers, showing benefits for biodiversity, long-term nutrient retention, soil biogeochemical cycling, biomass production, rooting, and infiltration. However, possible conflicts exist with tree management of establishment, thinning and harvesting, and habitat benefits that require further research.

\section{Moving from Traditional Vegetated Buffer Strips to Designed Multicomponent Buffer Zones}

This collection addresses the attainment of multiple benefits from buffers and how increasing intervention is required to enhance natural processes in certain (most likely intensively farmed) landscapes. We are currently moving away from the traditional VBSs (dry, highly infiltrating filter strips) that have been applied for decades, toward designed riparian buffer zones constructed to intercept agricultural surface and subsurface runoff pathways (Fig. 3). These new buffer concepts aim to assist more efficiently in interrupting flows of sediment, nutrients, and other contaminants, alongside increasing diversity in surface topography, moisture conditions, soil C, vegetation, and habitat.

Haddaway et al. (2018) identified research gaps regarding characteristics for improving multiple outcomes across diverse sites and pressures, and how multiple interventions targeting multiple outcomes led to synergies and/or conflicts. Many studies reported here documented multiple outcomes, exemplified by the ecosystem services assessment approaches combined in the assessment of IBZ designs (Zak et al., 2019). Studies here also reported varied effectiveness for nutrients-for example, where buffers are more effective at soluble $\mathrm{N}$ removal; dissolved P remains an issue (Valkama et al., 2019; Vidon et al., 2019). A range of widths was considered in the studies, but the suggestion is that narrow widths are less robust to key water quality functions (Dal Ferro et al., 2019; Jaynes and Isenhart, 2019). In general, there is great site specificity to buffers, meaning that width comes out less important than other key factors of vegetation, soil type, and biogeochemical processes, wetness, landscape context, and drainage pathways (Valkama et al., 2019). The proportionate and appropriate use of the growing "menu" of structural elements, from simple engineering principles acting on water flows to ecotechnologies incorporated in the riparian buffer space, is part of countering uncertainties in buffer functions and developing more robust solutions to landscape pressures on aquatic ecosystems. (Fig. 3). Reducing these uncertainties in buffer functions will be of increasing importance with intensifying pressures of climate, agriculture, and development.

The current collection shows a strong basis for taking simple principles of engineering into buffer designs with the aim of enhancing natural processes of nutrient attenuation. This includes interventions such as fueling denitrification with $\mathrm{C}$ substrates (Jansen et al., 2019), raising deeper groundwaters for exposure to topsoil organic C (Jaynes and Isenhart, 2019), or using tree root zones for nutrient attenuation (Zak et al., 2019). Such elements tackle long-standing issues for buffers such as subsurface pathways bypassing the buffer strip's actions. However, designed buffer zones may be hotspots for pollution swapping, including exchange of $\mathrm{NO}_{3}$ removed for $\mathrm{N}_{2} \mathrm{O}$ and dissolved organic $\mathrm{N}$ emitted, of sediment and particulate $\mathrm{P}$

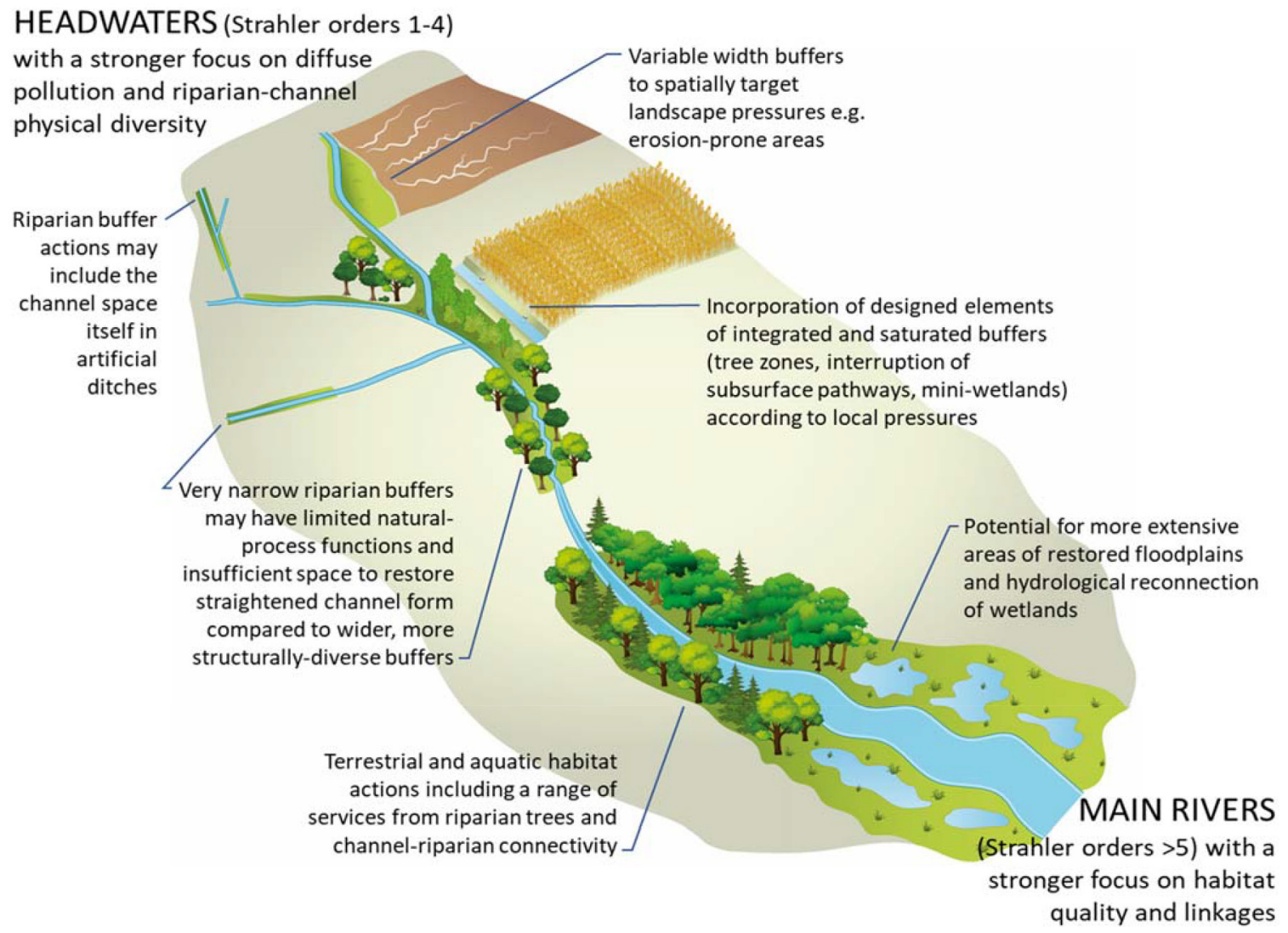

Fig. 3. An example of incorporating designed elements of riparian management into landscapes from headwaters to larger rivers, as should be developed as part of a multiobjective, catchment-scale plan. It is across such scales that knowledge provided by the current collection ought to be applied and tested to obtain technical evidence and stakeholder opinions toward improved riparian management implementation. 
for dissolved reactive and dissolved organic $\mathrm{P}$, and of emission of $\mathrm{CO}_{2}, \mathrm{CH}_{4}$, and labile DOC. In the current collection, one study is dedicated to GHGs (Davis et al., 2019), but further work needs to address GHG emission from dry and rewetted buffers as compared with adjoining cultivated land. There remains need for research to avoid, or at least lower, such pollution swapping in designed riparian buffers by avoiding overloading with nutrients and introducing different management schemes.

\section{Aspects Relating to Implementation and Uptake}

Payment structures for managing riparian buffer zones out of agricultural production have long been a key incentive for uptake. The current collection identifies that attainment of multiple ecosystem benefits should accrue stacked, long-term payments across differing societal and policy objectives (Dal Ferro et al., 2019). Evidence of possible multiple benefit attainment from buffers must now contribute alongside effective guidance toward outcome-based payments that become stacked across policy objectives. Perhaps this is made easier where overarching water policy exists, such as the EU Water Framework Directive. However, this is not yet integrated with other multiple benefits of flood mitigation, climate mitigation and adaptation, and terrestrial habitat, relevant to promoting riparian buffers (Voulvoulis et al., 2017). The situation is more complex in the United States, where many different state laws superimpose onto basic federal laws (Merrill, 2016) and mitigation funding may be targeted to problem-solving initiatives in major watersheds (Oelsner and Stets, 2019). Provision should be made to support ongoing management favoring continued benefits, not just initial creation and capital outlay. Declining habitat quantity and quality in intensively managed farmland is a key issue (Tscharntke et al., 2005), and improving terrestrial habitat is a long-accepted driver for implementation of buffers and funding. Wider benefits of promoting aquatic habitat conditions and resilience and climate services should also be recognized and incentivized. Studies here have addressed biomass benefits from buffers as persuasion for greater riparian buffer space (Dal Ferro et al., 2019; Hénault-Ethier et al., 2019; Zak et al., 2019). This collection offers messages regarding the handling of wood fuels to maximize economic returns and the integration of green manure as a small supplement within traditional fertilizer regimes on fields, but again, these topics need a consolidated evidence base going forward.

In better implementing future buffer zones, we need tools for their improved spatial targeting. This involves the appropriate planning of multiple objectives from headwaters to large river scales where differing pressures, processes, and required functions dictate different components than buffers (Fig. 3). The required "tools" combine spatial data resources (soil and topographic mapping, habitat designations, and opportunity mapping) but also ground survey, incorporation of local knowledge, legislative flexibility, and good guidance and communication). The current collection had few examples of upscaling the effects of buffers to larger catchment scales, but a basis for this exists in literature to be combined with more technical plot studies.

The number of options for edge of field technologies is limited presently but growing. Incorporation of trees is a widely accepted riparian intervention due to widespread public and farmer opinion that this is a natural and desired image of the countryside. However, farmers are more reluctant to accept so-called "engineered" features in riparian buffers due to a current lack of awareness and demonstration. Developments may be shared here with the natural flood management research community, who promote temporary water storage structures and sediment traps, primarily in riparian spaces and across ditches (EA, 2017). Such measures are effective in sediment and particulate pollutant control as well as flood management and, by tackling cross-sectoral objectives, may leverage funding. Buffer research (typically on terrestrial habitat and nutrient mitigation in rural environments) should now link with other disciplines (e.g., flood managers, agricultural engineers, agronomists, and urban water quality managers) to look widely for crossovers that may yield appropriate designs and accelerate the generation of evidence and guidance toward achieving more effective riparian buffers at catchment scales.

\section{Acknowledgments}

M. Stutter was supported by funding from Scottish Government's Rural and Environment Science and Analytical Services Division under the Strategic Research Program, Natural Assets Theme. B. Kronvang was supported by funding from the Danish Strategic Science Foundation (BufferTech) and the Nordic Centre of Excellence "BIOWATER" (Nordforsk Project no. 82263). Funding from the Irish Environmental Protection Agency (Specific Management and Robust Targeting of Riparian Buffer Zones, SmarterBufferZ; Grant 2017-W-LS-16) supported D. Ó hUallacháin and M. Stutter.

\section{References}

Benton, T.G., J.A. Vickery, and J.D. Wilson. 2003. Farmland biodiversity: Is habitat heterogeneity the key? Trends Ecol. Evol. 18:182-188. doi:10.1016/ S0169-5347(03)00011-9

Borin, M., M. Passoni, M. Thiene, and T. Tempesta. 2010. Multiple functions of buffer strips in farming areas. Eur. J. Agron. 32:103-111. doi:10.1016/j.eja.2009.05.003

Brodie, J.E., S.E. Lewis, C.J. Collier, S. Wooldridge, Z.T. Bainbridge, J. Waterhouse, et al. 2017. Setting ecologically-relevant targets for river pollution loads to meet marine water quality requirements for the Great Barrier Reef, Australia: A preliminary methodology and analysis. Ocean Coast. Manage. 143:136-147. doi:10.1016/j.ocecoaman.2016.09.028

Brown, L.K., C. Kazas, J. Stockan, C. Hawes, M. Stutter, C.M. Ryan, et al. 2019. Is green manure from riparian buffer strip species an effective nutrient source for crops? J. Environ. Qual. 48:385-393. doi:10.2134/jeq2017.11.0422

Christen, B., and T. Dalgaard. 2013. Buffers for biomass production in temperate European agriculture: A review and synthesis on function, ecosystem services and implementation. Biomass Bioenergy 55:53-67. doi:10.1016/j.biombioe.2012.09.053

Christianson, L.E., A. Bhandari, and M.J. Helmers. 2012. A practice-oriented review of woodchip bioreactors for subsurface agricultural drainage. Appl. Eng. Agric. 28:861-874. doi:10.13031/2013.42479

Dal Ferro, N., M. Borin, A. Cardinali, R. Cavalli, S. Grigolato, and G. Zanin. 2019. Buffer strips in the low-lying plain of Veneto region (Italy): Environmental benefits and efficient use of wood as energy resource. J. Environ. Qual. 48:280-288. doi:10.2134/jeq2018.07.0261

Daniels, R., and J. Gilliam. 1996. Sediment and chemical load reduction by grass and riparian filters. Soil Sci. Soc. Am. J. 60:246-251. doi:10.2136/ sssaj1996.03615995006000010037x

Davis, M.P., T.A. Groh, D.B. Jaynes, T.B. Parkin, and T.M. Isenhart. 2019. Nitrous oxide emissions from saturated riparian buffers: Are we trading a water quality problem for an air quality problem? J. Environ. Qual. 48:261-269. doi: $10.2134 /$ jeq2018.03.0127

Dillaha, T.A., R.B. Reneau, S. Mostaghimi, and D. Lee. 1989. Vegetative filter strips for agricultural non-point source pollution control. Trans. ASAE 32:05130519. doi: $10.13031 / 2013.31033$

Dorioz, J.M., D. Wang, J. Poulenhard, and D. Trevisan. 2006. The effect of grass buffer strips on phosphorus dynamics: A critical review and synthesis as a basis for application in agricultural landscapes in France. Agric. Ecosyst. Environ. 117:421. doi:10.1016/j.agee.2006.03.029

Dybkjær, J.B., A. Baattrup-Pedersen, H. Thodsen, and B. Kronvang. 2012. Diversity and distribution of riparian plant communities in relation to stream size and eutrophication. J. Environ. Qual. 41:348-354. doi:10.2134/jeq2010.0422

EA. 2017. Working with natural processes to reduce flood risk. Environ. Agency, Bristol, UK. www.gov.uk/government/publications/working-with-natural-processes-to-reduce-flood-risk (accessed February 2019).

Ferrarini, A., P. Serra, M. Almagro, M. Trevisan, and S. Amaducci. 2017. Multiple ecosystem services provision and biomass logistics management in bioenergy buffers: A state-of-the-art review. Renew. Sustain. Energy Rev. 73:277-290. doi:10.1016/j.rser.2017.01.052 
Fraters, D., E. Wattel, and K. Kovar, editors. 2017. International Interdisciplinary Conference on Land use and Water Quality: Effect of agriculture on the environment, The Hague, the Netherlands, 29 May-1 June 2017. Aarhus Univ., Aarhus, Denmark.

Groenenberg, J.E., W.J. Chardon, and G.F. Koopmans. 2013. Reducing phosphorus loading of surface water using iron-coated sand. J. Environ. Qual. 42:250-259. doi: $10.2134 /$ jeq2012.0344

Groh, T.A., M.P. Davis, T.M. Isenhart, D.B. Jaynes, and T.B. Parkin. 2019. In situ denitrification in saturated buffer zones. J. Environ. Qual. 48:376-384. doi:10.2134/jeq2018.03.0125

Habibiandehkordi, R., D.A. Lobb, P.N. Owens, and D.N. Flaten. 2019. Effectiveness of vegetated buffer strips in controlling legacy phosphorus exports from agricultural land. J. Environ. Qual. 48:314-321. doi:10.2134/jeq2018.04.0129

Haddaway, N.R., C. Brown, J. Eales, S. Eggers, J. Josefsson, B. Kronvang, et al. 2018. The multifunctional roles of vegetated strips around and within agricultural fields. Environ. Evidence 7:14. doi:10.1186/s13750-018-0126-2

Harrison, S.S.C., and I.T. Harris. 2002. The effects of bankside management on chalk stream invertebrate communities. Freshwater Biol. 47:2233-2245. doi:10.1046/j.1365-2427.2002.00939.x

Hénault-Ethier, L., M. Lucotte, É. Smedbol, M. Pedrosa Gomes, S. Maccario, M.E. Lamoureux Laprise, et al. 2019. Potential efficiency of grassy or shrub willow buffer strips against nutrient runoff from soybean and corn fields in southern Quebec, Canada. J. Environ. Qual. 48:352-361. doi:10.2134/jeq2016.10.0391

Hille, S., D. Graeber, B. Kronvang, G.H. Rubæk, N. Onnen, E. Molina-Navarro, et al. 2019. Management options to reduce phosphorus leaching from vegetated buffer strips. J. Environ. Qual. 48:322-329. doi:10.2134/jeq2018.01.0042

Hoffmann, C.C., C. Kjaergaard, J. Uusi-Kämppä, H.C.B. Hansen, and B. Kronvang. 2009. Phosphorus retention in buffers: Review of their efficiency. J. Environ. Qual. 38:1942-1955. doi:10.2134/jeq2008.0087

Jansen, S., R. Stuurman, W. Chardon, S. Ball, J.C. Rozemeijer, and J. Gerritse. 2019 Passive dosing of organic substrates for nitrate-removing bioreactors applied in field margins. J. Environ. Qual. 48:394-402. doi:10.2134/jeq2018.04.0165

Jaynes, D.B., and T.M. Isenhart. 2019. Performance of saturated riparian buffers in Iowa, USA. J. Environ. Qual. 48:289-296. doi:10.2134/jeq2018.03.0115

Kristensen, E., B. Kronvang, P. Wiberg-Larsen, H. Thodsen, C.B. Nielsen, E. Amor, et al. 2014. 10 years after the largest river restoration project in northern Europe: Hydromorphological changes on multiple scales in River Skjern. Ecol. Eng. 66:141-149. doi:10.1016/j.ecoleng.2013.10.001

Kronvang, B., E. Jeppesen, D. Conley, M. Søndergaard, S. Larsen, N. Ovesen, and J. Carstensen. 2005. An analysis of pressure, state and ecological impacts of nutrients in Danish streams, lakes and coastal waters and ecosystem responses to nutrient pollution reductions. J. Hydrol. 304:274-288. doi:10.1016/j. jhydrol.2004.07.035

Land, M., W. Granéli, A. Grimvall, C.C. Hoffmann, W.J. Mitsch, K.S. Tonderski, and J.T.A. Verhoeven. 2016. How effective are created or restored freshwater wetlands for nitrogen and phosphorus removal? A systematic review. Environ. Evid. 5:9. doi:10.1186/s13750-016-0060-0

Madden, D., S. Harrison, J.A. Finn, and D. Ó hUallachháin. 2015. Riparian buffer zones in intensive grassland agri-systems are not necessarily a refuge for high conservation value species. Biol. Environ. 115B:191-210. doi:10.3318/ bioe.2015.19

Mander, M., J. Tournebize, K. Tonderski, J.T.A. Verhoeven, and W.J. Mitsch. 2017. Planning and establishment principles for constructed wetlands and riparian buffer zones in agricultural catchments. Ecol. Eng. 103:296-300. doi:10.1016/j. ecoleng.2016.12.006

Mayer, P.M., S.K. Reynolds, M.D. McCutchen, and T.J. Canfield. 2007. Meta-analysis of nitrogen removal in riparian buffers. J. Environ. Qual. 36:1172-1180. doi: $10.2134 /$ jeq2006.0462

McCracken, D., L. Cole, W. Harrison, and D. Robertson. 2012. Improving the farmland biodiversity value of riparian buffer strips: Conflicts and compromises. J. Environ. Qual. 41:355-363. doi:10.2134/jeq2010.0532

Merrill, M. 2016. Riparian buffers: The lack of buffer protection policies and recommendations to expand protection. J. Environ. Law Litigation 30:65-86.

Naiman, R.J., H. Decamps, and M. Pollock. 1993. The role of riparian corridors in maintaining regional biodiversity. Ecol. Applications 3:209-212. doi: $10.2307 / 1941822$

O'Callaghan, P., M. Kelly-Quinn, E. Jennings, P. Antunes, M. O’Sullivan, O. Fenton, and D. Ó hUallacháin. 2019. The environmental impact of cattle access to watercourses: A review. J. Environ. Qual. 48:340-351. doi:10.2134/jeq2018.04.0167

Oelsner, G., and E.G. Stets. 2019. Recent trends in nutrient and sediment loading to coastal areas of the conterminous U.S.: Insights and global context. Sci. Total Environ. 654:1225-1240. doi:10.1016/j.scitotenv.2018.10.437

Penn, C., J. McGrath, J. Bowen, and S. Wilson. 2014. Phosphorus removal structures: A management option for legacy phosphorus. J. Soil Water Conserv. 69:51A56A. doi: $10.2489 /$ jswc.69.2.51A
Pilon, C., P.A. Moore, Jr., D.H. Pote, J.W. Martin, P.R. Owens, A.J. Ashworth, et al. 2019. Grazing management and buffer strip impact on nitrogen runoff from pastures fertilized with poultry litter. J. Environ. Qual. 48:297-304. doi:10.2134/jeq2018.04.0159

Pollock, M.M., R.J. Naiman, and T.A. Hanley. 1998. Plant species richness in riparian wetlands-a test of biodiversity theory. Ecology 79:94-105. doi:10.1890/0012-9658(1998)079[0094:PSRIRW]2.0.CO;2

Ricketts, T.H., J. Regetz, I. Steffan-Dewenter, S.A. Cunningham, C. Kremen, A. Bogdanski, et al. 2008. Landscape effects on crop pollination services: Are there general patterns? Ecol. Lett. 11:499-515. doi:10.1111/j.1461-0248.2008.01157.x

Rhoades, C. 2019. Soil nitrogen leaching in logged beetle-killed forests and implications for riparian fuel reduction. J. Environ. Qual. 48:305-313. doi:10.2134/ jeq2018.04.0169

Robinson, R.A., and W.J. Sutherland. 2002. Post-war changes in arable farming and biodiversity in Great Britain. J. Appl. Ecol. 39:157-176. doi:10.1046/j.1365-2664.2002.00695.x

Rodríguez-Cruz, M.S., J.M. Ordax, M. Arienzo, and M.J. Sánchez-Martín. 2011. Enhanced retention of linuron, alachlor and metalaxyl in sandy soil columns intercalated with wood barriers. Chemosphere 82:1415-1421. doi:10.1016/j. chemosphere.2010.11.059

Sabo, J.L., R. Sponseller, M. Dixon, K. Gade, T. Harms, J. Heffernan, et al. 2005. Riparian zones increase regional species richness by harboring different, not more, species. Ecology 86:56-62. doi:10.1890/04-0668

Schindler, D.W., S.R. Carpenter, S.C. Capra, R.E. Hecky, and D.M. Orihel. 2016. Reducing phosphorus to curb lake eutrophication is a success. Environ. Sci. Technol. 50:8923-8929. doi:10.1021/acs.est.6b02204

Singh, G., J.E. Schoonover, K.W.J. Williard, A.L. Sweet, and J. Stewart. 2019. Giant cane vegetative buffer for improving soil and surface water quality. J. Environ. Qual. 48:330-339. doi:10.2134/jeq2017.11.0452

Smart, S.M., R.H. Marrs, M.G. Le Duc, K. Thompson, R.G.H. Bunce, L.G. Firbank, and M.J. Rossall. 2006. Spatial relationships between intensive land cover and residual plant species diversity in temperate farmed landscapes. J. Appl. Ecol. 43:1128-1137. doi:10.1111/j.1365-2664.2006.01231.x

Strokal, M., L. Ma, Z. Bai, S. Luan, C. Kroeze, O. Oenema, et al. 2016. Alarming nutrient pollution of Chinese rivers as a result of agricultural transitions. Environ. Res. Lett. 11. doi:10.1088/1748-9326/11/2/024014

Stutter, M., W. Chardon, and B. Kronvang. 2012. Riparian buffer strips as a multifunctional management tool in agricultural landscapes: Introduction. J. Environ. Qual. 41:297-303. doi:10.2134/jeq2011.0439

Stutter, M.I., S.J. Langan, and D.G. Lumsdon. 2009. Vegetated buffer strips can lead to increased release of phosphorus to waters: An assessment of the mechanisms. Environ. Sci. Technol. 43:1858-1863. doi:10.1021/es8030193

Styles, D., P. Borjesson, T. D’Hertefeldt, K. Birkhofer, J. Dauber, P. Adams, et al. 2016. Climate regulation, energy provisioning and water purification: Quantifying ecosystem service delivery of bioenergy willow grown on riparian buffer zones using life cycle assessment. Ambio 45:872-884. doi:10.1007/ s13280-016-0790-9

Thorsøe, M.H., M. Graversgaard, and E. Noe. 2017. The challenge of legitimizing spatially differentiated regulation: Experiences from the implementation of the Danish Buffer Zone Act. Land Use Policy 62:202-212. doi:10.1016/j. landusepol.2016.12.030

Tscharntke, T., A.M. Klein, A. Kruess, I. Steffan-Dewenter, and C. Thies. 2005. Landscape perspectives on agricultural intensification and biodiversity-ecosystem service management. Ecol.Lett. 8:857-874. doi:10.1111/j.1461-0248.2005.00782.x

Uusi-Kämppä, J., E. Turtola, A. Närvänen, L. Jauhiainen, and R. Uusitalo. 2012. Phosphorus mitigation during springtime runoff by amendments applied to grassed soil. J. Environ. Qual. 41:420-426. doi:10.2134/jeq2010.0441

Valkama, E., K. Usva, M. Saarinen, and J. Uusi-Kämppä. 2019. A meta-analysis on nitrogen retention by buffer zones. J. Environ. Qual. 48:270-279. doi:10.2134/ jeq2018.03.0120

Vidon, P.G., M.K. Welsh, and Y.T. Hassanzadeh. 2019. Twenty years of riparian zone research (1997-2017): Where to next? J. Environ. Qual. 48:248-260. doi:10.2134/jeq2018.01.0009

Voulvoulis, N., K.D. Arpon, and T. Giakoumis. 2017. The EU Water Framework Directive: From great expectations to problems with implementation. Sci. Total Environ. 575:358-366. doi:10.1016/j.scitotenv.2016.09.228

Windolf, J., H. Tornbjerg, CC. Hoffmann, J.R. Poulsen, G. Blicher-Mathiesen, and B. Kronvang. 2016. Successful reduction of diffuse nitrogen emissions at catchment scale: Example from the pilot River Odense, Denmark. Water Sci. Technol. 73:2583-2589. doi:10.2166/wst.2016.067

Zak, D., M. Stutter, H. Jensen, S. Egemose, M. Vodder Carstensen, J. Audet, et al. 2019. An assessment of the multifunctionality of integrated buffer zones in northwestern Europe. J. Environ. Qual. 48:362-375. doi:10.2134/jeq2018.05.0216 